\title{
Do sermão do Diabo: o avesso da narrativa
}

Vera Casa Nova I UFMG

\author{
"Há muitos modos de afirmar, há só um \\ de negar tudo."
}

Machado de Assis

Resumo: Este artigo mostra como Machado de Assis, em "O sermão do Diabo", usa elementos retóricos para persuadir o leitor a uma teologia às avessas, estabelecendo, a partir da eloqüência e do poder da linguagem, um processo de transgressão e subversão dos pecados ditados pelo sermão de Deus.

Palavras-chave: elementos retóricos, subversão e transgressāo, Machado de Assis.

Em ensaio intitulado "Machado de Assis: teoria do medalhão - uma encruzilhada semiótica", tratei a retórica como dispositivo pedagógico de ensinamento da teoria (discurso) do pai para o filho. Apontei alguns momentos de uma argumentação no discurso machadiano, típica de um discurso político-cultural brasileiro em que a competência política se estruturava em cinismo e venalidade. O talento (moeda) assim se construía como um sentido produzido pela metafísica política, assegurado pelo medalhão.

1. CASA NOVA, 1992. 
Na igreja do Diabo, o narrador machadiano trata a metafísica enquanto enunciada pela retórica da negação. Como na teoria do medalhão, aposta no jogo das estratégias políticas, que se enunciam através de um discurso de poder às avessas, em que o discurso das escrituras se transforma em pecado. Enquanto as virtudes são apontadas no discurso da igreja de Deus como importantes para a salvação das almas, o Diabo as lê ao contrário, através de antinomias, numa teologia que ele constrói com a idéia do corpo dócil - as turbas corriam atrás dele entusiasmadas e messianicamente induzidas pelo pecado ou avesso das palavras e virtudes propaladas.

Assim, as virtudes naturais como a soberba, a luxúria, a preguiça, a avareza, a ira, a gula, a inveja, os famosos pecados são proclamados no centro de sua argumentação. Ao mesmo tempo em que a venalidade, a hipocrisia, a calúnia, o desrespeito, a adulação ocupam o espaço da vida nua e da vida política do indivíduo e da sociedade.

Deus e Diabo como forças antagônicas, numa encruzilhada do destino humano, corresponderiam a retóricas particulares, cada um representado pela sua igreja, respectivamente, ora afirmando, ora negando a ação humana, fascinando o humano... Siderações de ouvintes, quando a eloqüência torna imóveis escritura contra escritura, breviário contra breviário.

Sutil, esse velho retórico desafia o discurso da verdade sobre os homens. O cogito parece iniciar um longo processo de abalo. Há em "A igreja do Diabo" e "O sermão do Diabo" uma reflexividade e uma atualidade da consciência instaurada por uma orientação de experiência vivida, que tem a ver com uma imanência a si e ao processo de mundo.

Esses dois textos machadianos mostram uma lógica anti-divina, e uma propaganda diabólica. Lembro Vilém Flusser, em seu livro A história do Diabo, quando afirma que a própria Igreja católica oferece, via sedução, os pecados. Pecados que no fundo são inócuos e arcaicos e facilmente substituíveis por termos neutros e modernos. Afirma ainda Flusser: "Soberba é a consciência de si mesmo. Avareza é economia. Luxuria é instinto (ou afirmação da vida). Gula é melhora do standard de vida. Inveja é luta pela justiça social e liberdade política." ${ }^{2}$

Desclassificando o discurso da igreja e exaltando os pecados, o discurso do Diabo tenta eliminar a influência divina. Em seu sermão, o Diabo trabalha com

2. FLUSSER, 2006, p. 25. 
a semelhança, via diferença. Ou seja, a retórica é semelhante à do Evangelho e a argumentação é diferente, por ser contrária ao que é proposto pelo discurso cristão.

Bem-aventurados os que nascem finos, porque eles morrerão grossos. ${ }^{3}$

$\mathrm{Eu}$, porém,vos digo que não jureis nunca a verdade, porque a verdade nua e crua, além de indecente, é dura de roer; mas jurai sempre e a propósito de tudo, porque os homens foram feitos para crer antes nos que juram falso, do que nos que não juram nada. Se disseres que o sol acabou, todos acenderão velas... ${ }^{4}$

A racionalidade retórica machadiana pensa filosoficamente conceitos que a sociedade do fim do século XIX vê aflorarem desde sempre. Mesmo a questão da liberdade, tão cara a esse século, permanece na reflexão filosófica de todos os tempos e sobretudo na questão"o que é o homem, afinal?"

No manuscrito do Diabo brotam camadas ontológicas em planos distintos, sobretudo economia e política, que estão subjacentes nos pecados e na própria doutrina.

9ํㅡㄴ Vós sois o sal do money market. E se o sal perder a força, com que outra cousa se há de salgar?

[...]

$20^{\circ}$ Não queirais guardar para vós tesouros na terra, onde a ferrugem e a traça os consomem, donde os ladrões os tiram e levam.

[...]

$21^{\circ}$ Mas remetei os vossos tesouros para algum banco de Londres, onde a ferrugem, nem a traça os consomem, nem os ladrões os roubam, e onde ireis vê-los no dia do juízo.

Nesses aforismos do sermão incluem-se probabilidades que podem e devem ser integradas num sistema conceitual. Trata-se de opiniões do narradorautor sobre o mundo e a doxa. Há uma racionalidade como prática, não só por se referir às ações humanas (sentido aristotélico), mas por não ser uma racionalidade especulativa, puramente teórica, que deriva de um olhar sobre o humano.

3. MACHADO DE ASSIS, 1997b, p. 647.

4. MACHADO DE ASSIS, 1997b, p. 648.

5. MACHADO DE ASSIS, 1997b, p. 648. 
Valores universais estão presentes no discurso machadiano e não é uma simples técnica de retórica persuasiva, pois estão relacionados à poética, à ética, à política e à metafísica.

Há um logos que se estrutura a partir de um discernimento pessoal do autor. Lei de Deus X lei do Diabo, e mais uma vez o homem em Machado de Assis se encontra numa encruzilhada semiótica, engendrada pelo Diabo. Machado ainda está a nos dizer que o poder da linguagem e os perigos da retórica agem sobre "os espíritos e o coração". Fato é que pela arte da retórica pode-se persuadir o verdadeiro como o falso.

Eloqüência e espírito analítico mostram as sutilezas e a ironia que acompanham esse discurso de retórico sagaz e perspicaz. Ensinar (docere), emocionar (movere) e agradar (delectare) são os traços do discurso do Diabo que se adequam ao espaço da linguagem.

A receita de transgressão obedece a uma ordem e uma lógica de lugares (topoi). Vimos isso nos aforismos citados acima. Eles se ligam por efeitos e estão fundados sobre a estrutura do real e sobre valores atemporais. O leitor, diante de tanta eloqüência, acredita no que lê, ou quem sabe mesmo, devido aos ares teatrais da cena discursiva, ouve, estende para seu conhecimento essa tensão engendrada pela argumentação de contrários.

Texto diabólico por enfatizar uma ética do momento machadiano, baseada em um projeto crítico da sociedade, quando a cena da época parecia ser dominada pelas ações propostas pelo Diabo.

Dominação inconteste que Machado de Assis aponta para seus leitores e que abrange tanto o mundo externo quanto o íntimo. Sempre com a pitada da ironia machadiana a desmoronar verdades absolutas e a deslocar o leitor ingênuo.

A pose do narrador dessas páginas recolhidas é também diabólica, quando, temendo o Diabo, rendendo-se à sua sedução ou exconjurando-o, se despediu com o sinal da cruz, num gesto teatral: "Fiz-lhe uma cruz com os dedos e ele sumiu-se. Apesar de tudo, não respondo pelo papel, nem pelas doutrinas, nem pelos erros de cópia."

Divindade in(a)temporal, imortal, o Diabo de Machado de Assis tem em sua representação a figura do joker. Figura do aniquilamento das relações sociais e individuais, que é capaz de ser até mesmo antropofágica, como nessa passagem: "Amai-vos uns aos outros. Pois eu digo-vos: comei-vos uns aos outros; melhor é

6. MACHADO DE ASSIS, 1997b, p. 649. 
comer que ser comido; o lombo alheio é muito mais nutritivo que o próprio."

Fortemente popular, a figura do Diabo está mais próxima de nós que Deus. O Diabo subverte a ordem, mostrando que é mais fácil seguir seus ditames do que os de Deus. Projeto crítico, ético e estético que denuncia uma hipertrofia da moral de fin-de-siècle. O sorriso que o leitor descuidado é capaz de dar ao chegar ao final da narrativa é também o do arrepio, do riso nas lágrimas, marcado pelo ceticismo.

Nesses dois textos tem-se a visão dos múltiplos aspectos (positivos?) do caráter do Diabo e o avesso do sacro, o profano, capaz de fazer a sociedade se transformar, pelo seu poder de subversão e transgressão.

"O sermão do Diabo" pode mesmo ser considerado a doutrina da alegoria machadiana, por expor à luz a força inscrita em sua homenagem, em sua história.

Esse narrador diabólico não responde "pelo papel, nem pelas doutrinas, nem pelos erros de cópia”, pois estava prenunciando o fim da narrativa tradicional, as transformações estéticas que aconteciam no fim do século XIX e sobretudo as subversões políticas e mesmo teológicas.

Esse narrador estaria construindo um novo tipo de narratividade, estaria estabelecendo uma outra relação, tanto social como individual, com a morte e com o morrer. Não responde pelo papel, nem pelos erros de cópia, desorienta o leitor e marca a sua condição de um narrador que não tem mais como narrar.

Résumé: Cet article montre comment Machado de Assis dans le texte " $O$ sermão do Diabo" emploie des élements retoriques afin de persuader le lecteur à une téologie à rebours, qui établit un procès de transgression et subvertion des virtus, à partir de l'éloquence et du pouvoir du langage. dictés par le serment de Dieu.

Mots-clés: elements retoriques du discours du diable ;transgression et subvertion du discours de Dieu dans le texte O Sermão do Diabo de Machado de Assis.

7. MACHADO DE ASSIS, 1997b, p. 648. 
O eixo e a roda: $v .16,2008$

$$
\text { Referências }
$$

CASA NOVA, Vera Lúcia de Carvalho. Machado de Assis: teoria do medalhão - uma encruzilhada semiótica. Boletim do Cesp, v. 12, p. 36-44, 1992

MACHADO DE ASSIS, Joaquim Maria. A igreja do Diabo. In: —_. Histórias sem data (Obra completa). Rio de Janeiro: Nova Aguilar, 1997a. p. 369-374, v. 2.

MACHADO DE ASSIS, Joaquim Maria. O sermão do Diabo. In:____. Páginas recolhidas entre 1892/94 (Obra completa). Rio de Janeiro: Nova Aguilar, 1997b v.2 . p. 647-649, v. 2.

FLUSSER, Vilém. A história do Diabo. São Paulo: Annablume, 2006. 